THE ORIGINS OF CHINESE CIVILIZATION 


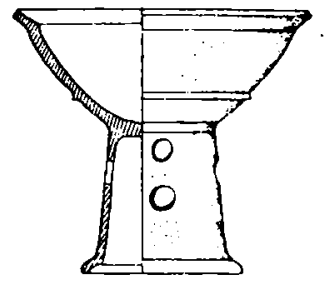

\section{THE ORIGINS}




\section{OF CHINESE CIVILIZATION}

With contributions by

NOEL BARNARD

K. C. CF:ANG

TE-TZU CHANG

CHEUNG KWONG-YUE

WAYNE H. FOGG

URSULA MARTIUS FRANKLIN

MORTON H. FRIED

W. W. HOWELLS

LOUISA G. FITZGERALD HUBER

KARL JETTMAR

DAVID N. KEIGHTLEY

FANG KUEI LI

HUI-LIN LI

WILLIAM MEACHAM

RICHARD PEARSON

E. G. PULLEYBLANK

ROBERT ORR WHYTE 


\section{STUDIES ON CHINA 1 \\ Sponsored by the Joint Committee on Chinese Studies \\ of the American Council of Learned Societies \\ and the Social Science Research Council}

\section{University of California Press}

Berkeley and Los Angeles, California

University of California Press, Ltd.

London, England

(C) 1983 by

The Regents of the University of California

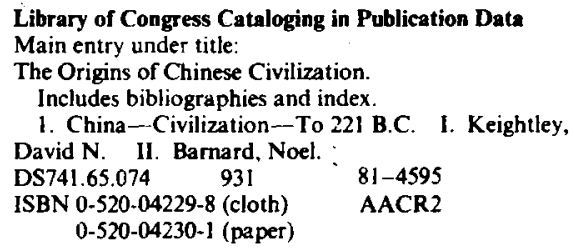

